\title{
The occurrence of Indian peanut clump, a soil-borne virus disease of groundnuts (Arachis hypogaea) in India*
}

\author{
BY D. V. R. REDDY, R. RAJESHWARI, N. IIZUKA†, D. E. LESEMANN \\ B. L. NOLT AND T. GOTO \\ Groundnut Improtement Program. International Crops Research Institute for the Semi-Arid \\ Tropics (ICRISAT), Patancheru P.O., Andhra Pradesh 502 324, India
}

(Accepted 30 September 1982)

\begin{abstract}
SUMMARY
A disease characterised by severely stunted plants with small dark green leaves was found in groundnut (Arachis hypogaea) in sandy soils in Punjab State. India. The disease occurred in patches in the field and reappeared in the same positions in succeeding groundnut crops. Plants infected early did not produce mature pods. Seeds sown in soil collected from infected fields produced plants with typical disease symptoms. Phaseolus vulgaris cv. Local and Chenopodium quinoa were found to be good diagnostic hosts. The disease was shown to be caused by a rod-shaped virus $c$. $24 \mathrm{~nm}$ in diameter with predominant particle lengths of c. 249 and $184 \mathrm{~nm}$ when stained in uranyl acetate. The virus, named Indian peanut clump virus (IPCV), resembled peanut clump virus (PCV) reported from $W$. Africa in symptomatology on groundnuts, particle morphology and soil-borne nature. However, it is not serologically related to two W. African PCV isolates tested, or to tobacco rattle (PRN and CAM strains) or pea early browning virus (Dutch isolate) in microprecipitin, enzyme linked immunosorbent assay and immunosorbent electron microscopy tests.
\end{abstract}

\section{INTRODUCTION}

A groundnut disease characterised by severe stunting of plants was first observed in Punjab State of India in 1977. The disease occurred in patches in the field and was restricted to crops raised in sandy and sandy loam soils. In Sangrur district of Punjab State the disease was present in every groundnut field surveyed in 1978 (Reddy et al., 1979). The disease is also economically important particularly on the crop raised in sandy soils in Andhra Pradesh, Gujarat, and Rajasthan States. It resembled clump disease of groundnut reported from India in 1927 by Sulidararaman (1927) and also a similar disease reported from W. Africa (Trochain, 1931; Bouhot, 1967; Germani \& Dhery, 1973; Thouvenel, Germani \& Pfeiffer, 1974). The disease occurring in W. Africa was shown to be caused by a virus called peanut clump (PCV) (Germani, Thouvenel \& Dhery, 1975: Thouvenel et al., 1974). This paper describes the symptoms of the disease in Punjab State, India, and some properties of the causal virus and its transmission. As our isolate appears to be serologically distinct from PCV in W. Africa, we have used the name Indian peanut clump virus (IPCV).

- Submitted as Journal Article No. 239 by the ICRISAT.

$\uparrow$ Visiting Scientist from Tropical Agriculture Research Centre; Present Address: Hokkajdo National Agriculture Experiment Station, Hitsujigaoka, Sapporo, Japan.

¥Bobegische Bundesanstalt fur Land.Und Forswirtschan, Institut fur Viruskrankheiten der Phanzen, Messewes $11 / 12$, D.3300 Braunschweig. W. Germany.

- 1983 Association of Applied Biologists 


\section{MATERIALS AND MFTHODS}

l'irus culture'. Groundnut plants showing characteristic symptoms were collected during surveys in Punjah State and virus cultures were established by graftinoculating healthy groundnut (cv. M 1.3). Mechanical inoculations were made from symptom hearing leaves by honogenising in $0.05 \mathrm{M}$ phosphate buffer $(\mathrm{pH} \mathrm{7.0)}$ containing $0.02 \mathrm{M} 2$ mercaptoethanol (PBM) and rubbing the extract on leaves of Chenopodium quinoa plants. A single lesion isolate was obtained by six successive single lesion transfers in $C$. quinoo and maintained hereafter in Nicotiana cletelandii $\times N$. glutinosa $(N$. hybrid).

Host runge. At least six plants of each species were inoculated and maintained in a screenhouse for 40 days at temperatures ranging between $20^{\circ} \mathrm{C}$ and $30^{\circ} \mathrm{C}$. Recovery assays were made on Phaseolus tulgaris cv. Local.

Phy'sical properties. The physical properties of the virus were determined using crude groundnut leaf extracts diluted to $10^{-1}$ in PBM. For determining thermal inactivation mint, $1 \mathrm{ml}$ samples of sap were heated for $10 \mathrm{~min}$ in a water bath. P. Iulgaris and $C$. quinoa were used as assay hosts.

Soil iransmission. Soil samples were collected at various depihs down in $25 \mathrm{~cm}$. from threc infected groundnut fields separated by a distance of at least $50 \mathrm{~km}$. At all three locations the disease reappeared in the same position in succeeding groundnut crops. Soil from infected fields was mixed with sterilised vermiculate and sand in the ratio of $2: 1: 1$. Groundnut seeds treated with thiram $(3 \mathrm{~g} / \mathrm{kg}$ seed) were sown in the mixture and watered with sterile water. Check plants were grown in a similar mixture but the soil from infected fields was steam sterilised before planting. Groundnut plants showing typical symptoms, and check plants were assayed on $\boldsymbol{P}$. l'ulgaris and by enzyme linked immunosorbent assay (ELISA).

Electron microscop!: Infected groundnut and $N$. hybrid leaves were cut into small pieces and fixed in 3\% glutaraldehyde prepared in $0.1 \mathrm{M}$ phosphate buffer, pH 7.3. for $1 \mathrm{~h}$. Fixed tissues were rinsed in phosphate buffer containing $0.5 \%$ sucrose, and cold phosphate buffer for $3 \mathrm{~h}$, post fixed in $2 \%$, osmium tetroxide for $3 \mathrm{~h}$ at room temperature and then washed with distilled water. Dehydration was accomplished in a graded series of acetone washes and the pieces were embedded in Epon 812. Ultrathin sections were cut with glass knives, stained with uranyl acetate and lead citrate (Venable \& Coggeshall, 1965) and examined in Philips model $201 \mathrm{C}$ electron microscope.

For detecting virus in extracts of infected plants, carbon-formvar or carbon-pioloform coated grids were floated for $5 \mathrm{~min}$ on drops of crude leaf extracts, washed with $\mathbf{4 0}$ drops of distilled water and stained with five drops of $2 \%$ aqueous uranyl acetate or $2 \%$ neutral sodium phosphotungstate.

For measuring the particle lengths, best results were obtained with crude extracts of infected $N$. clevelandii leaves fixed in $1 \%$ glutaraldehyde in $0.1 \mathrm{M}$ phosphate buffer, $\mathrm{pH} 7.0,(\mathrm{~PB})$ for 30 min, dialysed against $P B$ overnight and then used in immunosorbent electron microscopy (ISEM) (Lesemann, Bozarth \& Koenig. 1980; Roberts \& Harrison, 1979). The grids were coated for $5 \mathrm{~min}$ with $1 / 1000$ dilution of antiserum in PB, washed with 20 drops of PB, floated on drops of crude plant extracts for $15 \mathrm{~min}$, washed and stained as described above. Measurements of particles were made either from micrographs taken at calibrated magnification or directly from the screen of the Zeiss EM 10 electron microscope at a magnification of $100000 x$, with a Zeiss Morphomat 10 image analyser, using a carbon grating replica with 2160 lines per $\mathrm{mm}$ as length standard.

Serology. The virus was purified from N. hybrid (lizuka, Reddy \& Ghanekar, 1979). Infected leaves were homogenized in $0.1 \mathrm{M}$ phosphate buffer, pH 8.0. containing 1\% 2-mercaptoethanol, and the extract clarified with $10 \%$ chloroform. Virus was precipitated by adding $0.2 \mathrm{M} \mathrm{NaCl}$ and $6 \%$ polyethylene glycol, resuspended in $0.01 \mathrm{M}$ borate-phosphate buffer, $\mathrm{pH} 8.3$ and further purified by two cycles of rate zonal density gradient centrifugation in sucrose solutions. One $\mathrm{ml}$ 
of $1 \mathrm{mg}$ virus was emulsified with an equal volume of Freund's incomplete adjuvant and injected intramuscularly at weekly intervals, into New Zealand White rabbits. Serum was collected 2 wk after the fourth injection and titred by the precipitin ring test using purified virus $(150 \mu g / \mathrm{ml})$. Serological relationships were tested by microprecipitin. FLISA and ISEM tests. Micro precipitin tests were made on glass slides. Serial iwo-fold dilutions of antisera $(0.1 \mathrm{ml})$ were mixed with an equal volume of clarified plant extract, incubated at $37^{\circ} \mathrm{C}$ for $1-2 \mathrm{~h}$ in a moist chamber and examined under a dark field microscope.

Leaf extracts for ELISA were prepared in PBS $(0.02 \mathrm{M}$ phosphate buffer, $0.15 \mathrm{~m}$ sodium chloride, $0.003 \mathrm{M}$ potassium chloride. $\mathrm{pH} 7.4$ ) containing $0.05 \%$ Tween 20 and $2 \%$ polyvinylpyrrolidone, of mol. wi 40000 . All dilutions from keaf tissue were based on the original fresh weight. The ELISA was as described previously (Clark \& Adams. 1977, Lister, 1978). Wells in polystyrene micro ELISA plates (Dynatech Laboratories) were filled with $0.2 \mathrm{ml}$ of reagents. Coating globulin was used at 5.0 to $10 \mu \mathrm{g} / \mathrm{ml}$. Conjugated globulins of homologous antiserum were used at 1/300 dilution and those of heterologous antisera at 1/100 dilution. Heterologous antisera were to: two W. African isolates of PCV $(196,198)$, tohacco rattle virus (TRV) (CAM and PRN strains) and pea early browning virus (PEBV) (Dutch isolate). All ELISA reactions were assayed by reading absorbance at $405 \mathrm{~nm}$ in a Gilford 250 spectrophotometer. All tests were done in triplicate.

The basic procedure for ISEM is described above. Serial two fold dilutions of antisera (1/250, $1 / 500,1 / 1000$ and 1/2000) were used for coating the grids with each antisera. The grids were viewed at an instrument magnification of $40000 x$ and particle numbers on twelve viewing fields, chosen randomly from different grid squares, were counted on two duplicate grids. Results represent mean values from two grids.

\section{RESULTS}

Symptoms in groundnut. Under field conditions the disease always occurred in patches (Plate, fig. 1). Typical symptoms were observed on newly emerged 2-3 wk old seedlings. Plants were stunted and the new quadrifoliates showed mosaic mottling with chlorotic rings (Plate, fig. 2). Subsequently, the infected leaves turned dark green and showed faint mottling when viewed against light. Infected plants were conspicuous because of severe stunting and dark green leaves. Flowering occurred on infected plants but the pegs did not develop normal sized pods. Late infected plants produced small pods. Roots were dark coloured and the outer layers could be peeled off exposing a pink coloured inner layer. With the exception of the root symptoms, all the typical symptoms of the disease were reproduced on groundnuts infected with IPCV by mechanical inoculations of sap.

Host range. Canavalia ensiformis, Cassia obtusifolia, and Vicia faba produced necrotic local lesions. Chenopodium quinoa (Plate, fig. 3), Cyamopsis tetragonoloba and Vigna unguiculata (cv. C-152) produced chlorotic local lesions. The virus induced systemic veinal necrosis on Phaseolus vulgaris cvs. Local (Plate, Fig. 4) and Topcrop. Systemic mosaic symptoms were observed on Capsicum annuum, Cassia occidentalis, Crotalaria juncea, N. clevelandii, N. hybrid (Plate, fig. 5) and $N$. benthamiana.

The virus failed to infect the following hosts: Cajanus cajan cv. Sharda, Dalura stramonium, Glycine max cv. Bragg. N. rustica, N. tabacum cv. White Burley, Pisum satium cv. Bonneville and Vigna radiata.

Physical properties. The thermal inactivation point of the virus was between $60^{\circ} \mathrm{C}$ and $65^{\circ} \mathrm{C}$ and the dilution end point between $10^{-3}$ and $10^{-4}$. The virus remained infective for over 20 days at room temperature $\left(25^{\circ}-30^{\circ} \mathrm{C}\right)$.

Soil transmission. Of 160 groundnut seeds sown in soil collected at depth of 10 to $25 \mathrm{~cm}, 72$ produced seedlings with typical disease symptoms. Infectivity assays and ELISA detected IPCV 
in leaf extracts of diseased plants with $A_{103}$ readings of 0.8 to 1.1. None of 160 plants raised in sterilised soil showed disease symptoms and random assays using infectivity tests and ELISA ( $A_{40}$ readings ranged from $0.01-0.05$ ) failed to detect IPCV in 70 such plants.

Electron microscopy: In thin sections of infected tissue, masses of virus-like particles were ohserved arranged side by side in layers with the angle of their long axes in adjacent layers alternating to give a 'herring - bone' pattern (Plate, fig. 6).

Rod-shaped particles were observed in very low concentrations in leaf dip or spray preparations from leaf extracts of field-infected groundnut and mechanically-infected groundnut. $N$. hybrid and $N$. clevelandii. Using ISEM, 100-700 fold increase in the particle numbers over the uncoated or normal serum coated grids were oblained with IPCV antiserum coated grids and these were used for particle measurements. In uranyl acetate, particles had a diameter of $24 \pm 2$ $\mathrm{nm}$ and lengths of $249+8 \mathrm{~nm}$, and $184 \pm 4 \mathrm{~nm}$ (Plate, fig. 7). In phosphotungstate, the particles had a diameter of $20 \pm 1 \mathrm{~nm}$ and lengths of $2.39 \pm 13 \mathrm{~nm}$ and $169 \pm 5 \mathrm{~nm}$ (Text-fig. 1). In each stain many particles with lengths between 60 and $100 \mathrm{~nm}$ were observed but these were fewer in number after fixation of plant extracts with $1 \%$ glutaraldehyde suggesting that they were derived from the two main kinds of particles.

In phosphotungstate the particles showed a distinct central canal which was not seen in uranyl acetate. In uranyl acetate clear cross banding of the particles was visible with a periodicity of $2.5 \pm 0.2 \mathrm{~nm}$, calculated using the $2.55 \mathrm{~nm}$ value for tobacco rattle virus (Offord, 1966) as a standard.

Serology. The homologous antiserum titre was $1 / 600$ in the precipitin ring test. In microprecipitin tests, none of the dilutions of IPCV antiserum gave positive reaction with healthy leaf extracts of $N$. hybrid but a titre of $1 / 64$ was obtained with infected leaf extracts. Antisera to the two W. African PCV isolates, TRV, and PEBV did not react with healthy or infected $N$. hybrid leaf extracts.

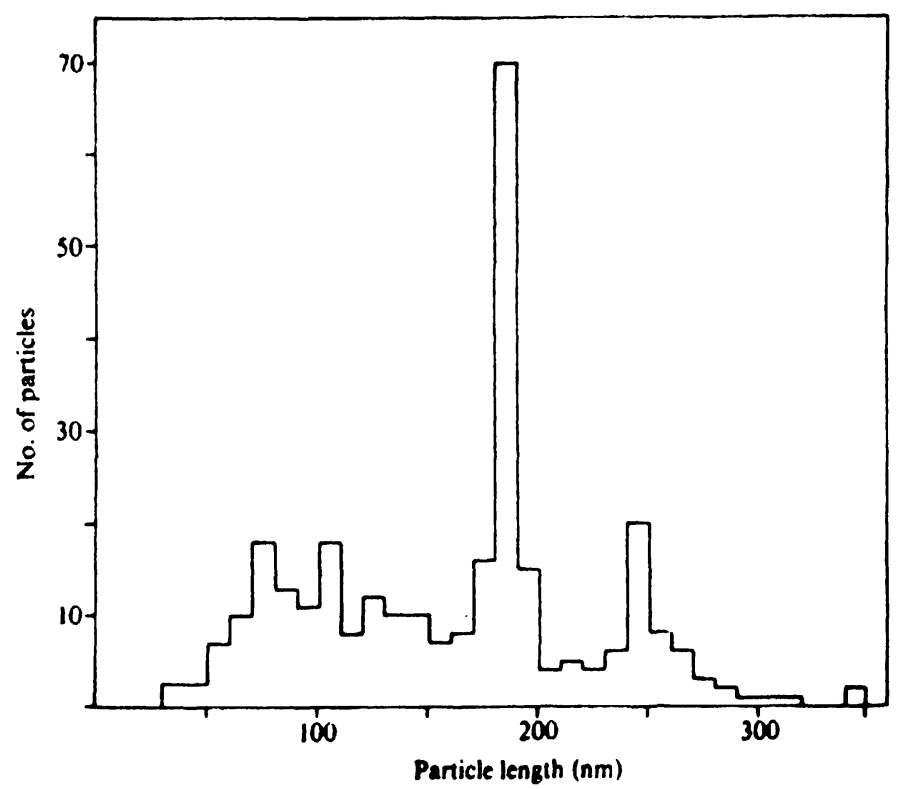

Text-fig. I. Histogram of length distribution of Indian peanut clump virus (IPCV). particles trapped with IPCV antiserum from crude leaf extract of $N$. clevelandii. fixed in $1 \%$ glutaraldehyde and stained with $2 \%$ uranyl acetate. 
In ELISA, leaf extracts from infected groundnut and $N$. hybrid had titres of $1 / 400$ and $1 / 1600$ respectively. The antiserum also detected purified virus to levels of about $100 \mathrm{ng} / \mathrm{ml}$. In tests using coating globulins of IPCV antiserum and purified IPCV at $10 \mu \mathrm{g} / \mathrm{ml}, A_{40}$ absorption values were $1 \cdot 1-1 \cdot 2$. In tests using coating globulins from antisera of the two $W$. African PCV isolates, two TRV isolates and PEBV. purified IPCV at $100 \mu \mathrm{g} / \mathrm{ml}$ and subsequently reacting with enzyme conjugates of IPC $V$ antiserum, $A_{40}$ absorption values were $0.05,0.07,0.03,0.06$ and 0.02 , respectively. Buffer controls and healthy plant extracts gave $A_{40}$ absorption values ranging from $0.03-0.09$.

In ISEM IPCV antiserum trapped 917 particles, W. African PCV 196 and PCV 198 trapped 13 and 11 particles, respectively, and normal rabbit serum trapped if particles. The various dilutions of antisera used for coating the grids did not influence the particle numbers.

\section{DISCUSSION}

This paper shows that clump disease which was recorded 55 years ago (Sundararaman. 1927) on groundnut in India is caused by a virus. The disease resembles PCV reported from W. Africa in that both the diseases produce similar symptoms in groundnut (Thouvenel. Dollet \& Fauquet, 1976), are soil-borne (Germani \& Dhery, 1973; Thouvenel et al., 1976), and are caused by morphologically similar virus particles (Germani et al., 1975: Thouvenel et al., 1976). However, in ELISA and microprecipitin tests W. African PCV isolates and IPCV from Punjab were serologically unrelated to one another and to any of the tobraviruses tested. Results of ISEM also showed that IPCV is unrelated to two W. African PCV isolates. Furthermore. PCV and IPCV show differences in host range: in uninoculated $P$. vulgaris leaves, IPCV produced systemic veinal necrosis and PCV mosaic symptoms and, unlike PCV, IPCV failed to infect $N$. tabacum cv. White Burley (Thouvenel et al.. 1976: Thouvenel \& Fauquet, 1981). The many broken particles present in IPCV. compared to PCV might indicate a greater instability of the Indian virus. Also, the greater particle diameter of IPCV in uranyl acetate could be explained by a flattening of particles prior to drying on the grid, which might again be caused by a greater instability of the particle structure.

From our recent surveys. IPCV is widely distributed in India and has been found to cause economic losses to the groundnut crop. Characterisation of IPCV isolates occurring in various parts of India. identification of the soil-borne vector, particle separation, chemical characterisation and large scale screening of exotic and Indian germplasm for sources of resistance are in progress.

We thank Drs D. McDonald and R. W. Gibbons for their valuable comments, Drs B. D. Harrison, C. Fauquet and L. Bos for supplying antisera, Drs J. S. Chohan, K. S. Labana and I. S. Sekhon of Punjab Agricultural University, Ludhiana for their cooperation in disease surveys and Mr Y. Bhaskar and S. K. Manohar for assistance in electron microscopy. One of us, D. E. L. gratefully acknowledges the financial support received from Deutsche Gesellschaft fur Technische Zusammenarbeit (GTZ) for the experiments conducted at Braunschweig.

\section{REFERENCES}

Воинот, D. (1967). Observations sur quelques affections des plantes cultivees au Senegal. Agronomic iropicale 22. 888-890.

CLARK. M. F. A ADAMS, A. N. (1977). Characieristics of the microplate method of enzyme linked immunosorbent assay for the detection of plant viruses. Journal of General Virolog.' 34. 475-483.

GERMANI. G. ^ DHERY, M. (1973). Observations et experimentations concernan le role des nematodes dans deus affections de l' Arachide en Haute-Volta: la 'chlorose' et le 'clump'. Oleagineux 28. 235-242.

OERMANi, G . THOUVENEL, J. C. D DHERY, M. (1975). Le rabougrissement de l'arachide: une maladie a virus au Senegal et en Hautc. Volta. Oleagineux 30. 259-266. 
IIZUKA, N., RFDDY, D. V. R. GHANFKAR. A. M. (1979). Identificalion of some viral diseases of groundnut in India. Simposium on legumes in the tropics. 13-17 November. Serdant. Malaysia. pn. 241-250

LESEMANN, D. E., DOZARTH, R. F. KOENiG, R. (1980). The trapping of tymovirus particles on electron microscope grids by adsorption and serological binding. Jowrnal of General Virolog. $42.57-264$.

USTER, R. M. (1978). Application of the enzyme linked immuncsorbent assay for detecting viruses in snytican seeds and plants. Phirtopatholog.' 68. 139.3-1400.

OFFORD, R. E. (1966). Electron microscopic observations on the substructure of tobacco rattle virus. Journal of Molecular Biolog!' 17. 370-375.

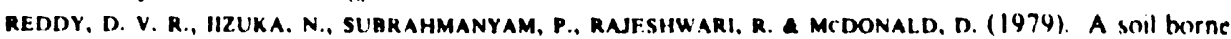
disease of peanuts in India. Proceedings of American Peanul Research and fiducation Sociely II. 49.

ROBERTS, I. M. HARRISON, B. D. (1979). Detection of potalo leafroll and potwto mop top viruses by immunosorbent electron inicroscopy. Annals of Applied Biologl 93. $289-297$.

Sunidararaman, S. (1927). A clump disease of groundnuts. Madras Agricultural Department Vear Book. 1926. Pp. 13-14

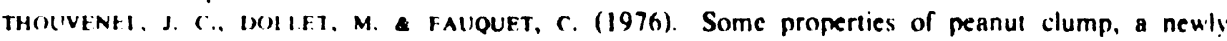
discovered virus. Annals of Applied Biolog!' 84, 311-320.

rhouvenel, J. C. FaliuUt, c. (1981). Further properties of peanut clump virus and studies on its natural transmission. Annals of Applied Biolog!' 97, 99-107.

thouventel, J. C., Gekmani. G. \& Pfeiffer (1974). Preuve de l'origine virale du robougrissement ou "clump" de l'Arachide en Haute. Volta et au Senegal. Comptes-rendus hebdomadaire des seances de l'Academie des Sciences 278. 2847-2849.

ткоснаin, J. (1931). La "lepre de l'Arachide". Retue de Botaniquee el Agriculture Tropicale II. 330-334.

venable, J. H. COGgeshall, R. (1965). A simplified lead citrate stain for use in electron microscopy. Journal of Cell Biolog.' 25, 407-408.

(Received 14 May 1982)

\section{EXPLANATION OF PLATE}

Fig. 1. Groundnut plants showing an area affected by Indian peanut clumn virus (IPCV).

Fig. 2. Typical mosaic symptoms with chlorotic rings induced by IPCV in groundnut.

Fig. 3. Chlorotic local lesions in Chenopodium quinoa induced by IPCV.

Fig. 4. Systemic veinal necrosis on primary leaves of Phaseolus uulgaris cv. Local induced by IPCV.

Fig. 5. Systemic mosaic symptoms induced by IPCV on Nicotiana clevelandii $\times N$. glutinosa.

Fig. 6. Electron micrograph of a thin section of leaf of IPCV-infected groundnut showing masses of virus particles arranged side by side with their long axes almost at right angles to the face of layer. Bar represents $400 \mathrm{~nm}$.

Fig. 7. Purified IPCV particles stained with $2 \%$ uranyl acetate showing the cross banding pattern. Bar represents 40 nm. 


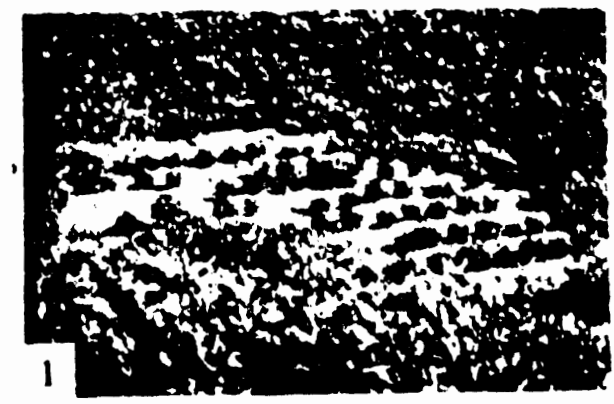

in

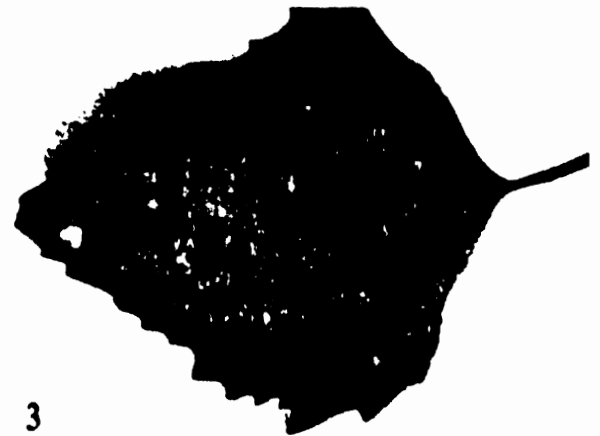
2.
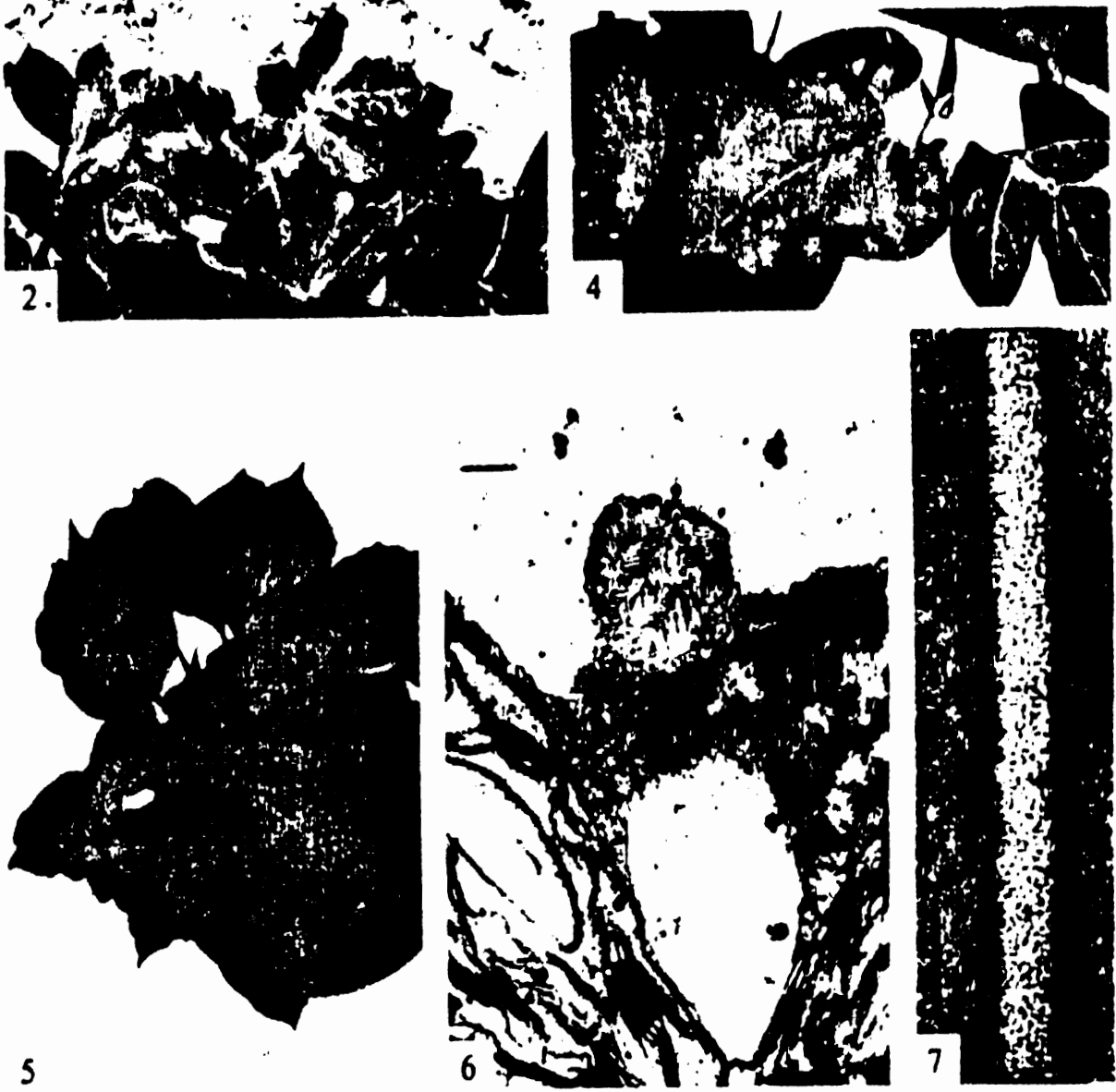